\title{
Reptiles in Monterey pine plantations of the Coastal Range of Central Chile
}

\author{
Sandra V Uribe* and Cristián F Estades
}

\begin{abstract}
Background: In Chile, most of the timber industry depends on Monterey pine (Pinus radiata (D. Don.)) plantations, which now cover more than 1.5 million ha. In spite of the intensive management of these plantations, they are home to a large number of wildlife species. One of the least known groups in this type of environment are reptiles. For this reason, we conducted a study on the distribution and abundance of reptiles at plantations of different ages in seven sites in the Coastal Range of Central Chile.

Results: From seven species that could be potentially found in the study region, a total of five species were recorded, with Liolaemus lemniscatus (Gravenhorst) being the most abundant (with up to 160 ind $^{*} \mathrm{a}^{-1}$ ). Detectability of species was similar in young and mature plantations but Liolaemus tenuis (Duméril and Bibron), the most colorful species, showed a higher detection probability than the other species. The highest abundance of reptiles was found in young plantations, and the density of L. lemniscatus and Liolaemus chiliensis (Lesson) declined significantly with plantation development. Liolaemus schroederi (Müller and Hellmich) increased significantly its numbers in 4- to 5-year-old plantations and remained with similar densities in mature plantations. L. tenuis density was low in all plantations and showed no relationship with age. The snake Philodryas chamissonis (Wiegmann) was recorded very few times and only in young plantations. Vegetation characteristics explained a significant proportion of the variation in the abundance of reptiles, with dense understories negatively affecting the abundance of lizards, likely by reducing the amount of heat and sunlight reaching the plantation's interior. The type of microhabitats with the highest number of lizard records was scrub and harvest debris.
\end{abstract}

Conclusions: This work confirms the role of pine plantations as habitat for an important proportion of reptile species in South Central Chile and provides some relationships with management variables that can be used to enhance the contribution of these artificial forests to biodiversity conservation.

Keywords: Abundance; Detectability; Habitat use; Understory; Plantation; Lizard

\section{Background}

The Chilean timber industry is based largely on Monterey pine plantations (Pinus radiata D. Don), which cover more than 1.5 million ha in the country (INFOR 2007). Although these intensively managed plantations are considered among the most economically successful forest systems of the world (Clapp 2001), there is a growing evidence that the pine plantations of Central Chile support an important number of wildlife species (Estades and Escobar 2005; Saavedra and Simonetti 2005).

\footnotetext{
*Correspondence: levsfor@uchile.cl

Laboratorio de Ecología de Vida Silvestre, Facultad de Ciencias Forestales y de la Conservación de la Naturaleza, Universidad de Chile, Casilla 9206, Santiago, Chile
}

However, one of the least studied wildlife groups in pine plantations are reptiles. Recently, Rubio and Simonetti (2011) compared the lizard community in a fragmented Nothofagus forest with that of the surrounding pine plantations. These authors recorded a higher number of species in plantations than in the native forest, although the tree-dwelling (Manzur and Fuentes 1979) Liolaemus tenuis (Duméril and Bibron) was more abundant in the native forests.

In spite of the physiognomic homogeneity of pine plantations, their structure and composition vary with the stand's age and management. These variables significantly influence the development and complexity of the understory, which is one of the most important attributes defining the

\section{Springer}


usefulness of pine plantations for wildlife (e.g., Estades and Escobar 2005; Zúñiga et al. 2009; Estades et al. 2012).

In order to contribute to the understanding of the role of forest plantations in the conservation of wildlife in Chile, we analyzed the patterns of reptile abundance in Monterey pine plantations of different ages in the Coastal Range of Central Chile.

\section{Methods}

This study was carried out in seven sites dominated by Monterey pine plantations in the Coastal Range of Central Chile (Figure 1, Table 1). This region was originally covered by deciduous forests of Nothofagus glauca (Phil.) Krasser (Gajardo 1994) most of which were cut during the last two centuries, first to provide land for agriculture and later, for exotic forest plantations (San Martín and Donoso 1996).

We assessed the use of pine plantations by reptiles through 65 4-ha $(200 \times 200 \mathrm{~m})$ sampling plots in which we characterized the vegetation and estimated the abundance of the different species. The distribution of sampling plots per site, plantation age, and year of evaluation are indicated in Table 1.

Because of the rapid changes of the vegetation in young plantations (and the resulting shading), we divided young plantations into two age classes ( 1 to 2 years, $N=15$ and 4 . to 5 years, $N=15$ ) that have clear different structures (Table 2). Two sites, Melencura-Name and Montezorro, did not have these age classes (Table 1). The sampled mature stands $(N=35)$ were approximately 17 to 18 years old, 2 to 3 years younger than the normal harvest age.

In each sampling plot, we established four 0.04-ha $(20 \times 20 \mathrm{~m})$ subplots in which we thoroughly searched

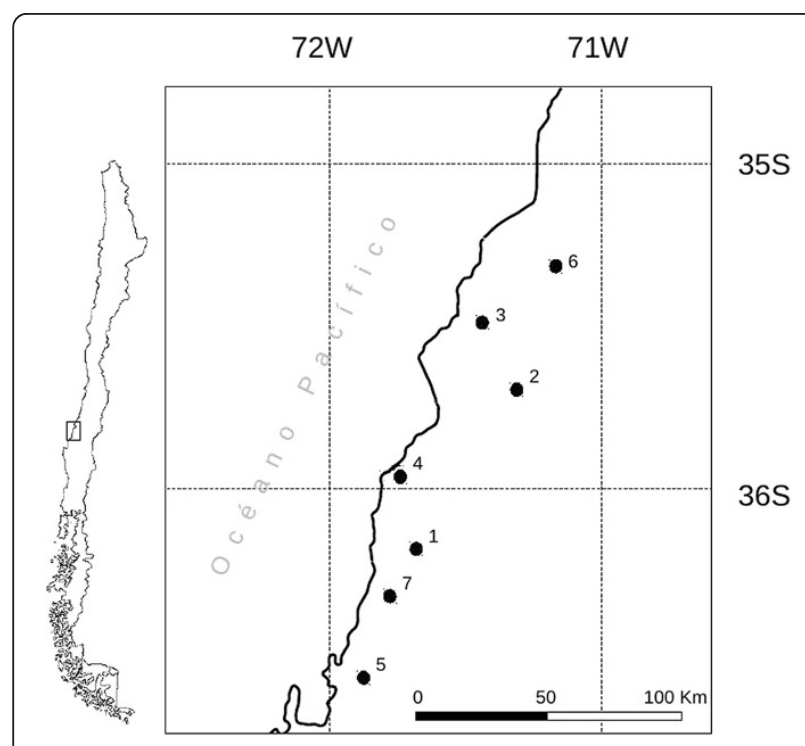

Figure 1 Geographical location of study sites (numbers refer to those used in Table 1). for reptiles. The search was conducted by a trained observer who walked slowly and systematically in parallel lines during $30 \mathrm{~min}$, recording all observed individuals. We tried to avoid double counts by using as many features as possible to identify individuals (e.g., amputated tails, size, color, etc.).

For each detected individual, we visually estimated the perpendicular distance to the observer's advancement line at the moment of the first sighting. These data were used for the construction of detectability curves (Buckland et al. 2001), necessary for correcting density estimates. When possible, we classified individuals in age classes (adult, juvenile, or hatchling). Also, we recorded the substrate on which individuals were located when first sighted.

Sampling was conducted only during the summer (December-February) and on sunny days, before noon. However, because factors such temperature, wind, etc., can significantly affect reptile detectability, we reduced the latter effect by searching each plot in two different days, with a maximun of 10 days among visits. Finally, for each plot, we estimated population density using the average obtained the four subplots and the two visits $(N=30$ in young plantations and $N=35$ in mature plantations).

In order to correct density estimates for detectability, we divided the raw (observed) values by the detection probabilities between 0 and the maximum observation distance $(4 \mathrm{~m})$ (Buckland et al. 2001). For each species, we calculated the detection probability density function recording the individual observation frequencies in $0.5 \mathrm{~m}$ distance ranges and dividing them by the maximum frequency in all ranges (setting to 1 the maximum value). Records in the 0 to 0.5 and 0.5 to $1 \mathrm{~m}$ ranges were averaged to correct for the early escape effect of some individuals. We used the unmarked package (Fiske and Chandler 2011) for the latter calculations.

As part of a different study, in each sample plot, we characterized vegetation in terms of foliage volume (see Estades and Temple 1999). Although we produced estimates of the total foliage volume $\left(\mathrm{m}^{3 *} \mathrm{ha}^{-1}\right)$ for each plot (see averages in Table 2), for the present study, we only used the data for the vegetation under $2 \mathrm{~m}$ of height (i.e., understory). For the analyses, we grouped different plant species into the following categories: pine (PINE), hygrophilous (HYGRO), sclerophyllous (SCLER), and exotic (EXOT) species. We also calculated the total understory volume (UTOT).

We used a stepwise regression (stepAIC procedure in R) analysis to study the factors influencing the density of the different reptile species in the studied plantations. For this purpose, we used the $\mathrm{LN}($ density +1$)$ as the dependent variable and the different vegetation variables as predictors. We also included latitude (UTMN), distance to the coast (DCOAST), and evaluation year (YEAR) as covariables. 
Table 1 Study sites, with administrative information and sampling effort

\begin{tabular}{|c|c|c|c|c|c|c|}
\hline & \multirow[t]{2}{*}{ Site } & \multirow[t]{2}{*}{ Locations } & \multirow[t]{2}{*}{ Company } & \multicolumn{2}{|c|}{ Sample plots $(n)$} & \multirow{2}{*}{$\begin{array}{c}\text { Evaluation } \\
\text { year }\end{array}$} \\
\hline & & & & Young pine & Adult pine & \\
\hline 1 & Tollo-Guanaco & Quirihue - Cobquecura (Biobío) & Masisa & 6 & 5 & 2008-2009 \\
\hline 2 & Melencura-Name & Empedrado (Maule) & Celco & - & 5 & 2008-2009 \\
\hline 3 & San Pedro y Las Cañas & Las Cañas (Maule) & Mininco & 6 & 5 & 2009-2010 \\
\hline 4 & Tregualemu & Tregualemu (Maule) & Masisa & 6 & 5 & 2009-2010 \\
\hline 5 & Crisoles-Manantiales-Leonera & Coelemu - Dichato (Biobío) & Masisa & 6 & 5 & 2010-2011 \\
\hline 6 & Quivolgo & Carrizal (Maule) & Celco & 6 & 5 & 2010-2011 \\
\hline 7 & Montezorro & Coelemu (Biobío) & Celco & - & 5 & 2011-2012 \\
\hline
\end{tabular}

Analyses for young and mature plantations were carried out separately. All analyses were conducted with the $\mathrm{R}$ system (R Development Core Team 2008).

\section{Results}

Four lizard species (Liolaemus lemniscatus Gravenhorst, Liolaemus schroederi Müller and Hellmich, Liolaemus chiliensis Lesson and L. tenuis) and one snake (Philodryas chamissonis Wiegmann) were detected during this study.

Figure 2 shows as an example the detection probability functions (half-normal distribution) for L. schroederi in adult and young plantations juveniles where the high resemblance between the two curves is evident. A similar situation was observed for L. lemniscatus and L. tenuis. For this reason, for each species, only one detectability function was used for the different plantations.

Figure 3 compares the detectability curves (half-normal distribution) for the three species in which the data allowed their calculation. Because of the limited number of data, for L. chiliensis and P. chamissonis, we did not calculate detectability functions. Thus, for the estimation of the density of $L$. chiliensis, we used the average of the correction factors for the other lizard species. The latter criterion is based on the assumption that, in the absence of better information, a 'general' detectability curve for Liolaemus lizards (average for three species) will produce a better estimation than not performing any corrections at all which, by definition, represents an understimation. However, we did not apply this criterion to P. chamissonis, which is morphologically and behaviorally very different from the other species, and we, therefore, considered its density as underestimated.
Figure 4 shows the abundance (ind ${ }^{*} \mathrm{ha}^{-1} \pm 1 \mathrm{SE}$ ) of the studied lizard species in plantations of different ages. The most abundant species was L. lemniscatus with an average of more than 160 ind $^{*} \mathrm{ha}^{-1}$ in young plantations. This density declined significantly ( $p<0.05$, GLM) to less than 35 ind*ha $^{-1}$ in mature plantations (Figure 4). The second most abundant species was L. schroederi, whose density increased significantly $(p<0.05$, GLM) from 14 to 50 ind $^{*} \mathrm{ha}^{-1}$ in 4 - to 5 -year plantations, maintaining a similar density in mature plantations (Figure 4). The other species were clearly less abundant. L. tenuis showed average densities ranging from 5 to 7 ind $^{*} \mathrm{ha}^{-1}$, but without a trend related to plantation age, whereas $L$. chiliensis, showed a pattern similar to that of L. lemniscatus, but with densities lower than 5 ind $^{*} \mathrm{ha}^{-1}$ (Figure 4). $P$. chamissonis had very few records producing an estimate of 0.2 ind $^{*} \mathrm{ha}^{-1}$ in young plantations and 0 ind $^{*} \mathrm{ha}^{-1}$ in mature stands, although some individuals were observed out of the sample in these plantations.

Abundances of L. schroederi and L. lemniscatus varied in relation to some vegetation variables (Table 3 ). Thus, in young stands, there was a positive effect of pine foliage volume on the abundance of $L$. schroederi, whereas in mature plantations, this species was affected positively by the amount of foliage in the understory and negatively by the foliage volume of exotic species (Table 3). The abundance of L. lemniscatus in young plantations was negatively associated with foliage volume in the understory. Finally, species richness (species/plot) was positively affected by pine foliage volume in young plantations and negatively by the foliage volume of exotic plants in mature plantations (Table 3).

Table 2 Vegetation characteristics at different plantation ages

\begin{tabular}{lllllr}
\hline Age & \multicolumn{1}{c}{ PINE } & \multicolumn{1}{c}{ NATIVE } & \multicolumn{1}{c}{ EXOT } & HYGRO & SCLER \\
\hline 1 to 2 & $1,807(446)$ & $1,644(350)$ & $2,332(541)$ & $311(129)$ & $365(162)$ \\
4 to 5 & $12,114(1,286)$ & $4,668(647)$ & $13,472(1,255)$ & $1,025(379)$ & $842(230)$ \\
17 to 20 & $44,140(3,853)$ & $15,992(1,304)$ & $45,589(3,984)$ & $5,100(565)$ & $4,574(618)$ \\
\hline
\end{tabular}

Mean (standard error) foliage volume $\left(\mathrm{m}^{3 *} \mathrm{ha}^{-1}\right.$ ) of pine (PINE), native (NATIVE), exotic (EXOT), hygrophilous (HYGRO) and sclerophyllous (SCLER) species at different plantation ages (years). 

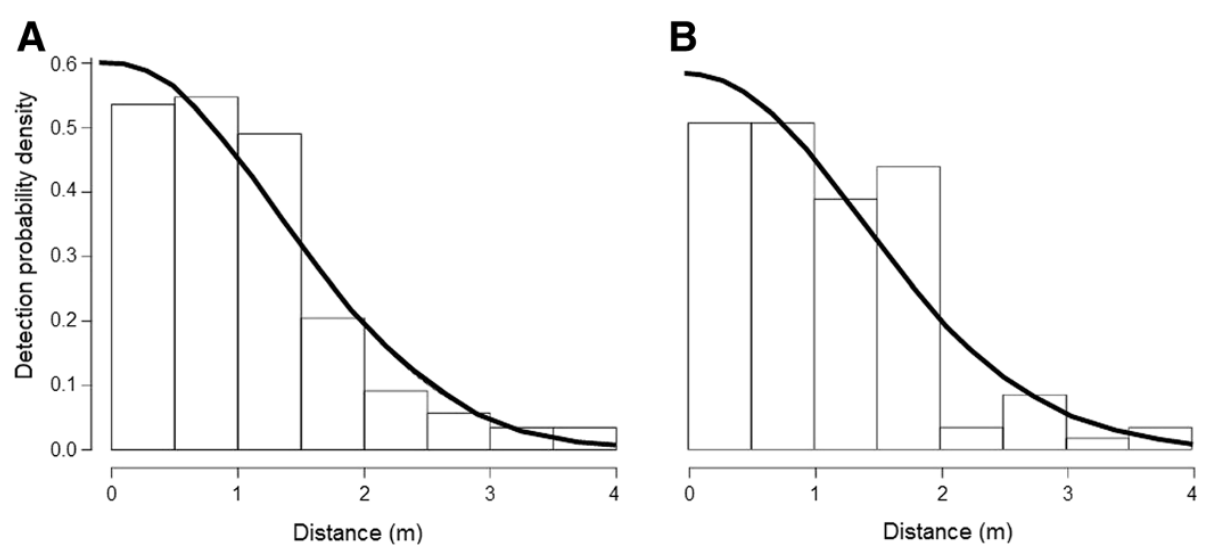

Figure 2 Detection probability density functions (half-normal distribution) for L. schroederi in (A) mature and (B) young plantations.

Most individuals of the different species that could be classified in an age class were adults, and the proportion between age groups did not vary between plantation types. The juvenile/adult ratio in L. lemniscatus was 0.38 $(136 / 359)$ in young plantations and $0.42(35 / 82)$ mature stands $\left(\chi^{2}=0.17, P=0.68\right)$. In the case of $L$. schroederi, this ratio was $0.53(39 / 73)$ in young plantations and 0.37 $(45 / 117)$ in the mature ones $\left(\chi^{2}=1.23, P=0.27\right)$. For L. tenuis the proportion was $0.35(6 / 17)$ in young stands and $0.45(9 / 20)$ in mature plantations $\left(\chi^{2}=0.01, P=0.92\right)$. Finally, we recorded only $20 \%$ of juveniles (3/15) of $L$. chiliensis during this study.

In young plantations, L. lemniscatus was recorded mostly on the ground (Figure 5A), as opposed to $L$. schroederi $\left(\chi^{2}=91.2, P<0.001\right)$ and L. tenuis $\left(\chi^{2}=31.9\right.$,

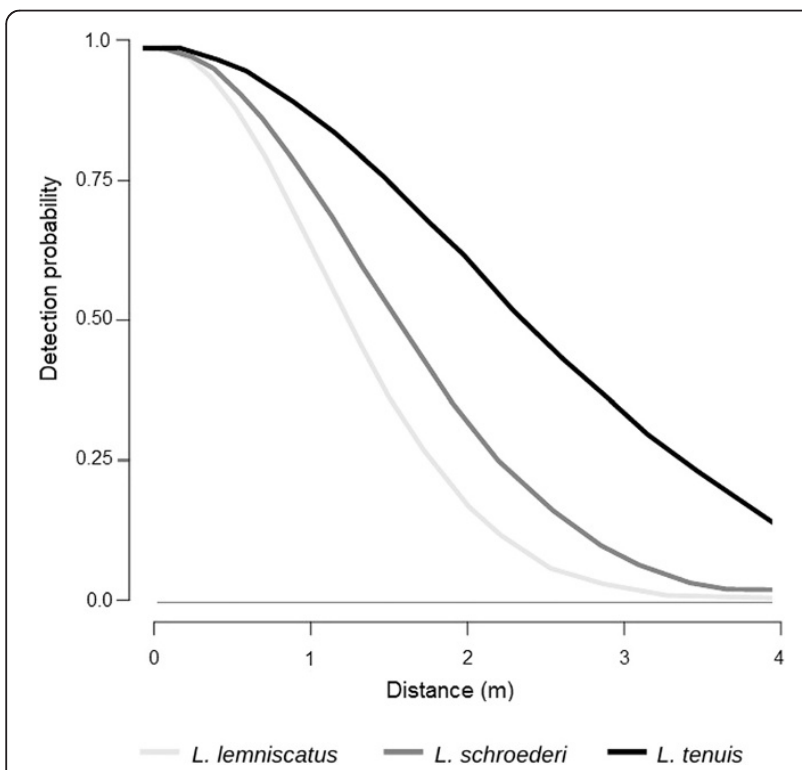

Figure 3 Comparison between detectability curves (half-normal distribution) of L. lemniscatus, L. schroederi, and L. tenuis.
$P<0.001)$ that used mostly shrubs and harvest debris as their main substrate (Figure 5A). There were no significant differences in the substrate use pattern of L. schroederi and L. tenuis $\left(\chi^{2}=1.4, P=0.49\right)$ (Figure $\left.5 \mathrm{~A}\right)$. In mature stands, patterns were similar, with a higher presence of L. lemniscatus on the ground and a lower use of shrubs and pruning debris (Figure 5B) than L. schroederi $\left(\chi^{2}=18.6, P<0.001\right)$ or $L$. tenuis $\left(\chi^{2}=29.5, P<0.001\right)$. However, there were differences between $L$. schroederi and L. tenuis because the latter showed a significantly lower frequency of records on the ground $\left(\chi^{2}=15.5, P<0.001\right)$ (Figure 5B). Because of the low number of records, no assessment of microhabitat use by $L$. chiliensis was conducted. Finally, we did not analyze the potential differences in microhabitat use between plantation types because we did not assess the availability of the different substrates.

\section{Discussion}

Different sampling techniques have different efficacies in the detection of reptiles (Travis et al. 2002). The method used by us is efficient for the study of lizards because of their relatively easy detection when they move in response to the advancement of the observer. However, because of their more secretive behavior, the abundance of snakes such as $P$. chamissonis is likely underestimated by this technique. Our failure to detect the snake Tachymenis chilensis (Schlegel) is probably due to the same effect, because, despite its general preference for wetter sites (Donoso-Barros 1966), it has been previously recorded in other pine plantations of the study region (Escobar pers. comm.).

Because of the higher amount of shadow and foliage cover under $2 \mathrm{~m}$ (height range most likely to affect observer's vision), mature pine plantations should present more obstacles for reptile observation than younger stands. However, in our study, detectability curves were similar in both mature and new plantations. A potential explanation for the latter is that, precisely because of the higher 
L. lemniscatus
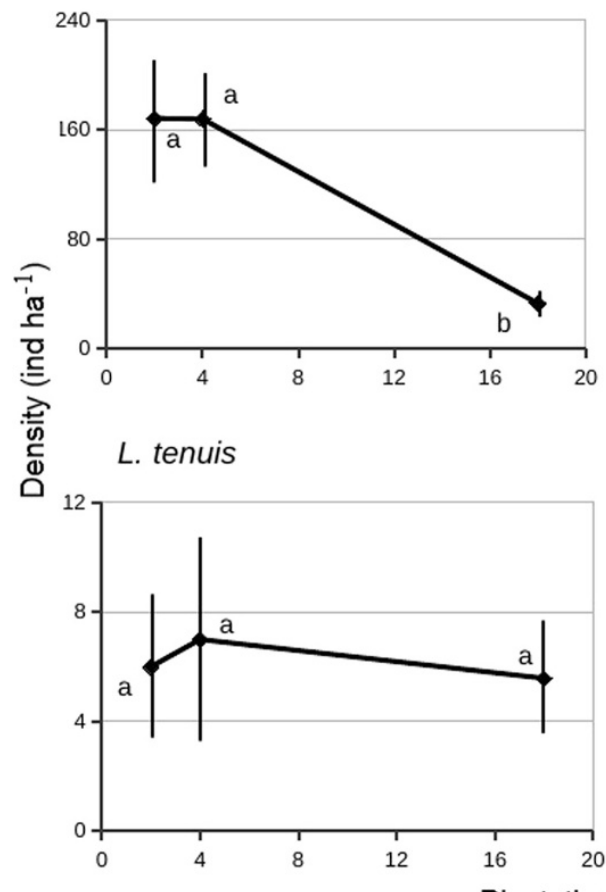

L. schroederi

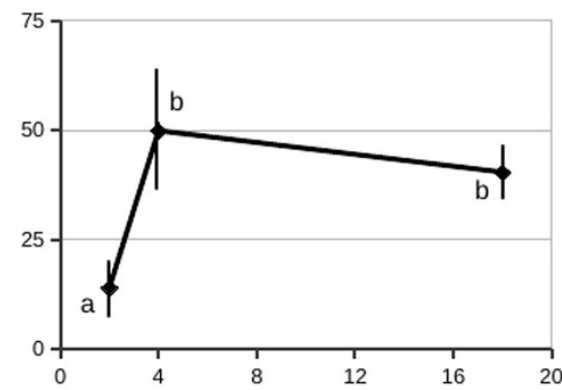

L. chiliensis

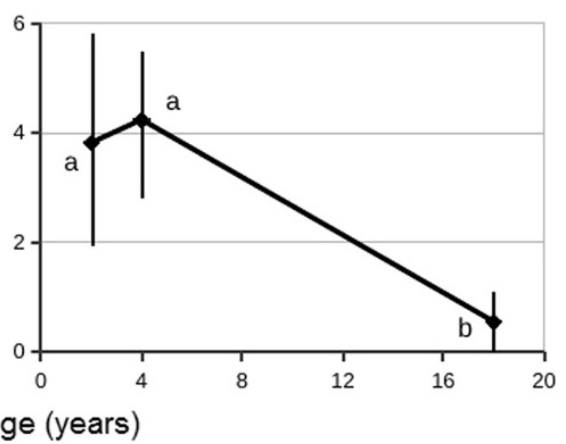

Figure 4 Density of different lizard species in plantations of different ages.

shadow environment in mature plantations, individuals might actively seek spots with direct sunlight (Carothers et al. 1998), making them more visible, and counteracting the effects of vegetation density on detectability. In the case of L. tenuis, its higher detectability compared to the other species is likely related to its conspicuous coloration and its climbing habits (Carothers et al. 1998). These observations highlight the importance of including the effects of detectability in the assessment of reptile populations (Mazerolle et al. 2007).

In the present study, we recorded four species of lizards common to pine plantations in the Coastal Range of Central Chile. There are other three species that have been reported from this type of environment, but that are rarer in
Central Chile. Liolaemus cyanogaster (Duméril and Bibron) has been observed in $P$. radiata plantations in Tregualemu (Mella 2005; Rubio and Simonetti 2011), particularly in the vicinity of native forests (Mella 2005). The arboreal lizard Pristidactylus torquatus (Philippi) has also been recorded in pine plantations (Méndez et al. 2005), although the northern limit of its coastal distribution practically coincides with the southern limit of our study region. A similar situation exists for Liolaemus pictus (Duméril and Bibron), whose coastal distribution runs from the Bío Bío river to the South (Ortiz and Ibarra-Vidal 2005).

In contrast to the results obtained by Rubio and Simonetti (2011) who only found one lizard species (L. tenuis) in the mature plantations, in our study, we recorded all four species

Table 3 Effects of vegetation attributes on reptile abundance and richness

\begin{tabular}{|c|c|c|c|c|c|c|c|c|}
\hline & \multicolumn{4}{|c|}{ Young plantations } & \multicolumn{4}{|c|}{ Adult plantations } \\
\hline & Model & & $R^{2}$ & $p$ value & Model & & $R^{2}$ & $p$ value \\
\hline L. chiliensis & - & & - & - & & & - & - \\
\hline L. lemniscatus & - & & - & - & UTOT $(-)^{* * *}$ & & 0.53 & $<0.0001$ \\
\hline L. schroederi & UTOT(+)' & $\operatorname{PINE}(+)^{* *}$ & 0.43 & 0.0002 & UTOT $(+)^{*}$ & EXOT $(-)^{* *}$ & 0.29 & 0.01 \\
\hline L. tenuis & - & & - & - & - & & - & - \\
\hline Richness & $\operatorname{PINE}(+)^{* *}$ & & 0.14 & 0.02 & $\operatorname{EXOT}(-)^{* * *}$ & & 0.31 & 0.0003 \\
\hline
\end{tabular}

(+) Positive relationship among dependent variable and independent(s) variable(s).

$(-)$ Negative relationship among dependent variable and independent(s) variable(s). ' $p<0.1 ;{ }^{*} p<0.05 ;{ }^{* *} p<0.01$; ${ }^{* * *} p<0.001$. For codes see Methods. 
A

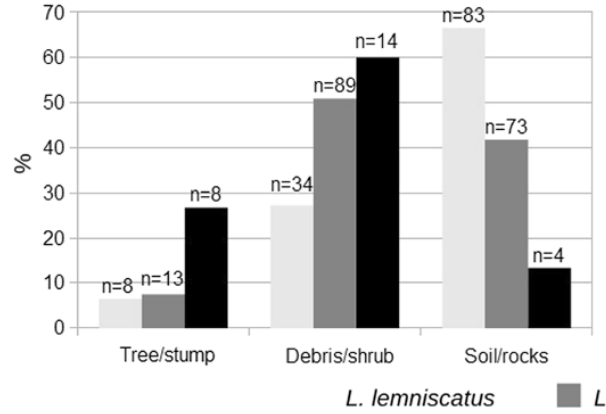

B

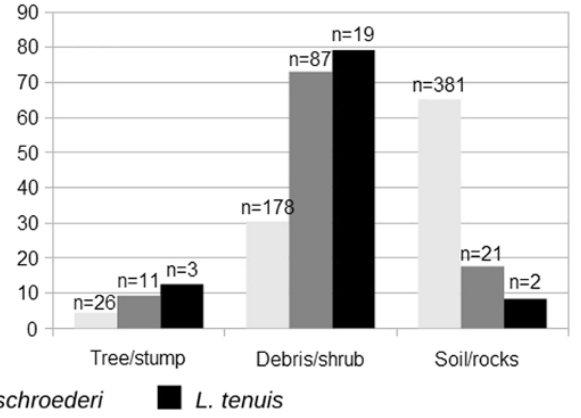

Figure 5 Proportion of recordings in different substrates for L. lemniscatus, L. schroederi, and L. tenuis in young (A) and mature plantations (B).

in the young and the mature stands. In spite of the latter, there were clear changes in the abundances of these species with plantation age (Figure 4), with the only exception being the arboreal lizard L. tenuis (Carothers et al. 1998; Rubio and Simonetti 2011), whose abundance was relatively the same in plantations of all ages. Both L. lemniscatus and L. chiliensis reduced significantly their abundances in mature plantations, in accordance to their preference for open habitats (Donoso-Barros 1966, Jaksic et al. 1980, Carothers et al. 1998).

L. schroederi, a species normally associated to shrubland (Jaksic et al. 1980), significantly increased its abundance in the 4- to 5-year plantations compared to the 1 - to 2 -year stands. This is probably due to the fact that 1 - to 2 -year plantations have a poorly developed shrubby layer. This pattern is also supported by the positive association of the species' abundance and pine foliage volume in young plantations, likely because young pines resemble shrubs.

The lack of light and heat reaching the forest floor affects negatively ground-dwelling reptile species (Amo et al. 2006; Todd et al. 2008), which would explain the negative effect of the understory on the abundance of $L$. lemniscatus. We do not have a clear explanation for the negative effect of the exotic foliage volume on the abundance of $L$. schroederi and species richness, but it might be related to a potential effect on the availability of food (e.g., fewer insects), among other mechanisms.

Our data indicate that, in young plantations, the changes in the vegetation and its role as habitat for reptiles may occur at a very fast pace. Contrary to our results, Rubio and Simonetti (2011) found a lower density of $L$. lemniscatus in young plantations that in mature stands. However, this might be explained by the fact that areas studied by these authors had been harvested during the previous year and probably had not had the time to develop adequate herbaceous and shrubby layers.

The use of different substrates by lizards in pine plantations followed the same pattern reported for natural ecosystems, with L. lemniscatus associated to the ground and the herbaceous layer (Donoso-Barros 1966; Carothers et al. 1998), L. schroederi using the shrubs (and harvest debris) (Jaksic et al. 1980) and L. tenuis with a higher use of trees (Carothers et al. 1998), although in absolute numbers, it used more the shrubs and harvest debris.

The lack of differences in the proportion of juveniles and adults among young and mature stands suggests that both types of plantation might play a similar role in the population dynamics of the different species. However, without information on the movement of individuals between plantations of different ages, a more complex dynamics (e.g., source-sink, etc.) cannot be ruled out.

Our results show how the development of pine plantations significantly influences the abundance of the different reptile species. In addition to the obvious requirements of food and refuges, for ectotherms, a crucial factor is the amount of sunlight that enters the ecosystem. Besides affecting the development of the understory, the lack of pruning and thinning reduces the incidence of solar radiation in the plantation floor (Eguiguren 1995) making it cooler. On the contrary, even in natural forests, thinning has been shown to significantly increase the density of reptiles (Todd et al. 2008).

Plantations of fast-growing tree species such as the Monterey pine are usually harvested through clearcutting. This means that, at the end of the rotation (approximately 20 years in Central Chile), large areas of mature plantations are cleared up producing two types of potential impacts on reptile populations. First, there is the evident change in the biophysical characteristics of the site that may reduce or increase its value as habitat for different species, as was shown in our study. Second, the felling of thousands of trees and the movement of heavy machinery constitute a potentially important mortality source, particularly for the less mobile species. However, the only study on the subject that we are aware of reported a relatively low mortality $(<2 \%)$ of timber rattlesnakes (Crotalus horridus) associated to forest logging operations in the United States 
(Reinert et al. 2011). This study suggests that the capacity of individuals to find refuge in burrows might play an important role in their survival during this stage.

Site preparation techniques might also affect the diversity and abundance of reptiles in pine plantations. For example, leaving harvest debris in the site should favor species such as $L$. schroederi and $L$. tenuis, whereas their extraction (an increasingly common practice motivated by the demand for biofuels) could probably harm them. Likewise, the use of herbicides or fire as management tools can have negative effects on reptiles and other vertebrates (Enge and Marion 1986; Hartley 2002; Todd et al. 2008).

Although the ultimate goal of forest plantations is the production of timber and fiber, there is an increasing evidence that they may play an important role in the conservation of biodiversity because they host large numbers of native plants and animals, particularly when they are managed through schemes that are known to favor wildlife (Hartley 2002; Lindenmayer and Hobbs 2004; Simonetti et al. 2012). In fact, in the present study, the densities of some of the recorded lizard species suggest that pine plantations in Central Chile have a significant impact on their regional demographics, with, literally, millions of individuals living in these artificial forests.

\section{Conclusions}

This study confirms the role of pine plantations as habitat for an important proportion of reptile species in South Central Chile. Not only these artificial forests are inhabited by several species but some of them, such as the lizard L. lemniscatus, can reach very high densities, with up to 160 ind"ha $^{-1}$ in new stands. Different lizard species respond differently to plantation development, with open-habitat species, such as L. lemniscatus and L. chiliensis decreasing their abundances as plantations age, whereas L. schroederi, a scrubland species, reaches its maximum densities in mid-aged to mature plantations. This knowledge can be used to enhance the contribution of pine plantations to biodiversity conservation in Chile.

\section{Competing interests}

The authors declare that they have no competing interests.

\section{Authors' contributions}

SVU designed the study, collected data and drafted the manuscript. CFE designed the study, carried out the statistical analyses, results interpretation and writing of the manuscript. All authors read and approved the final manuscript.

\section{Acknowledgements}

We thank the important contribution of two anonymous referees who helped to improve the quality of this work. This study was funded by a Fondecyt (1080463) grant to C. Estades. Masisa, Celco, and Mininco kindly allowed us to conduct this study in their properties, along with providing us with cartographic information and some logistic support. A large number of people helped during the different stages of this project, particularly, Martín Escobar, Roberto Thomson, María Angélica Vukasovic, Ana María Venegas, Romina Chiappe, and Jimena Bustos.
Received: 19 June 2014 Accepted: 22 October 2014

Published online: 06 November 2014

\section{References}

Amo L, López P, Martin J (2006) Natural oak forest vs. ancient pine plantations: lizard microhabitat use may explain the effects of ancient reforestations on distribution and conservation of Iberian lizards. Biodivers Conser 12:3409-3422

Buckland ST, Anderson DR, Burnham KP, Laake JL, Borchers DL, Thomas L (2001) Introduction to Distance Sampling. Oxford University Press, Oxford

Carothers JH, Marquet PA, Jaksic FM (1998) Thermal ecology of a Liolaemus lizard assemblage along an Andean altitudinal gradient in Chile. Rev Chil Hist Nat 71:39-50

Clapp RA (2001) Tree farming and forest conservation in Chile: do replacement forests leave any originals behind? Soc Natur Resour 14:341-356

R Development Core Team (2008) R: A language and environment for statistical computing. R Foundation for Statistical Computing, Vienna, Austria. ISBN 3900051-07-0, URL: http://www.R-project.org. (Accessed March, 26th 2012).

Donoso-Barros R (1966) Reptiles de Chile. Ediciones Universidad de Chile, Santiago

Equiguren F (1995) Caracterización florística del sotobosque en plantaciones de Pinus radiata D. Don de la provincia de Arauco, VIII Región. Tesis de Título, Facultad de Ciencias Agrarias y Forestales. Universidad de Chile, Santiago

Enge KM, Marion WR (1986) Effects of clearcutting and site preparation on herpetofauna of a North Florida flatwoods. Forest Ecol Manag 4:177-192

Estades CF, Escobar MAH (2005) Los ecosistemas de las plantaciones de pino de la Cordillera de la Costa. In: Smith-Ramírez C, Armesto JJ, Valdovinos C (eds) Historia, Biodiversidad y Ecología de los Bosques Costeros de Chile, 1st edn. Editorial Universitaria, Santiago

Estades CF, Temple SA (1999) Deciduous-forest bird communities in a fragmented landscape dominated by exotic pine plantations. Ecol Appl 9:573-585

Estades CF, Grez AA, Simonetti JA (2012) Biodiversity in Monterey Pine Plantations. In: Simonetti JA, Grez AA, Estades CF (eds) Biodiversity conservation in agroforestry landscapes: challenges and opportunities, 1st edn. Editorial Universitaria, Santiago

Fiske I, Chandler R (2011) Unmarked: an R package for fitting hierarchical models of wildlife occurrence and abundance. J Stat Softw 43:1-23

Gajardo R (1994) La Vegetación Natural de Chile. Clasificación y Distribución Geográfica. Editorial Universitaria, Santiago

Hartley MJ (2002) Rationale and methods for conserving biodiversity in plantation forests. Forest Ecol Manag 155:81-95

INFOR (2007) Estadísticas Forestales Chilenas 2006. Boletín Estadístico 117 Instituto Forestal, Santiago

Jaksic FM, Núñez H, Ojeda FP (1980) Body proportions, microhabitat selection, and adaptive radiation of liolaemus lizards in central Chile. Oecologia 45:178-181

Lindenmayer DB, Hobbs RJ (2004) Fauna conservation in Australian plantations forests - a review. Biol Conser 119:151-168

Manzur Ml, Fuentes ER (1979) Poligyny and agonistic behavior in the treedwelling lizard Liolaemus tenuis (iguanidae). Behav Ecol Sociobiol 6:23-28

Mazerolle MJ, Bailey LL, Kendall WL, Royle JA, Converse SJ, Nichols JD (2007) Making great leaps forward: accounting for detectability in herpetological field studies. J Herpetol 41:672-689

Mella J (2005) Guía de campo Reptiles de Chile: Zona Central. CEA Ediciones, Valdivia

Méndez MA, Soto ER, Torres-Pérez F, Veloso A (2005) Anfibios y Reptiles de los Bosques de la Cordillera de la Costa (X Región Chile). In: Smith-Ramírez C, Armesto JJ, Valdovinos C (eds) Historia, Biodiversidad y Ecología de los Bosques Costeros de Chile, 1st edn. Editorial Universitaria, Santiago

Ortiz JC, Ibarra-Vidal H (2005) Anfibios y Reptiles de la Cordillera de Nahuelbuta. In: Smith-Ramírez C, Armesto JJ, Valdovinos C (eds) Historia, Biodiversidad y Ecología de los Bosques Costeros de Chile, 1st edn. Editorial Universitaria, Santiago

Reinert HK, Munroe WF, Brennan CE, Rach MN, Pelesky S (2011) Response of timber rattlesnakes to commercial logging operations. J Wildlife Manage 75:19-29

Rubio AV, Simonetti JA (2011) Lizard assemblages in a fragmented landscape of central Chile. Eur J Wildlife Res 57:195-199

Saavedra B, Simonetti JA (2005) Small mammals of maulino forests remnants, a vanishing ecosystem of south central Chile. Mammalia 69:337-348

San Martín J, Donoso C (1996) Estructura Florística e Impacto Antrópico en el Bosque Maulino de Chile. In: Armesto JJ, Villagrán C, Arroyo MTK (eds) Ecología de los Bosques Nativos de Chile, 2nd edn. Editorial Universitaria, Santiago 
Simonetti JA, Grez AA, Estades CF (eds) (2012) Biodiversity conservation in agroforestry landscapes: challenges and opportunities. Editorial Universitaria, Santiago

Todd BD, Andrews KM (2008) Response of a reptile guild to forest harvesting Conserv Biol 22:753-761

Travis J, Ryan TJ, Philippi T, Leiden YA, Dorcas ME, Wigley TB, Gibbon JW (2002) Monitoring herpetofauna in a managed forest landscape: effects of habitat types and census techniques. Forest Ecol Manag 167:83-90

Zúñiga A, Muñoz-Pedreros A, Fierro A (2009) Uso del hábitat de cuatro carnívoros en el sur de Chile. Gayana 73:200-201

doi:10.1186/s40693-014-0025-z

Cite this article as: Uribe and Estades: Reptiles in Monterey pine plantations of the Coastal Range of Central Chile. Revista Chilena de Historia Natural 2014 87:25.

\section{Submit your manuscript to a SpringerOpen ${ }^{\circ}$} journal and benefit from:

- Convenient online submission

- Rigorous peer review

- Immediate publication on acceptance

- Open access: articles freely available online

- High visibility within the field

- Retaining the copyright to your article 